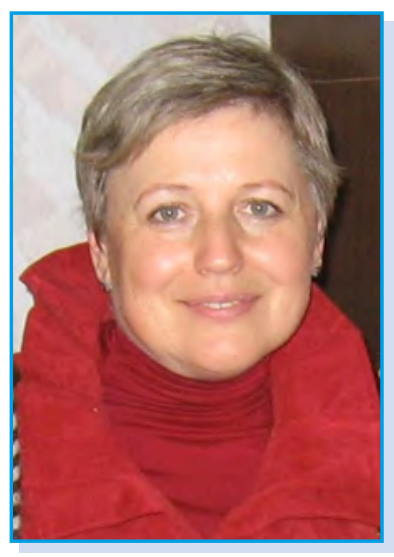

Наталія Гавриш - головний науковий співробітник лабораторії дошкільної освіти і виховання Інституту проблем виховання НАПН України, доктор педагогічних наук, професор, м. Київ, Україна.

Коло наукових інтересів: дослідження теоретичних і практичних проблем дошкільної освіти; розроблення Концепції дошкільної освіти, Базового стандарту дошкільної освіти, програм дошкільної освіти; методик і технологій комунікативно-мовленнєвого і соціального розвитку дітей раннього і дошкільного віку.

n.rodinaga@ukr.net

https://orcid.org/0000-0002-9254-558X

УДК 37.091.2:-053.4:373.22

https://doi.org/10.32405/2411-1317-2021-4-222-231

\title{
ОСОБЛИВОСТІ ОРГАНІЗАЦІЇ ОСВІТНЬО-ВИХОВНОГО ПРОЦЕСУ В ГРУПАХ РАННЬОГО ВІКУ ЗАКЛАДІВ ДОШКІЛЬНОї ОСВІТИ РІЗНИХ ТИПІВ
}

Висвітлено попередні результати дослідження особливостей організації освітньо-виховного процесу в групах раннього віку в закладах дошкільної освіти різних типів (дитячий садок, центр розвитку дитини, дитячий будинок), здійсненого в межах науково-дослідної діяльності. На основі теоретичного аналізу досліджуваної проблеми, практики роботи груп раннього віку закладах дошкільної освіти обгрунтовано необхідність дотримання спільних вимог щодо організації життєдіяльності, розвивального середовища та освітньо-виховного процесу в групах раннього віку з урахування специфіки їх функціонування. Зроблено зіставний аналіз особливостей освітньовиховного процесу в дитячому будинку та закладі дошкільної освіти з урахуванням пливу умов життєдіяльності дітей на становлення і розвиток психічних процесів і базових особистісних якостей малюків, привчання їх до правил, забезпечення міжособистісної взаємодії дітей між собою і з дорослим у різних видах активності. Представлено окремі якісні результати проведеного дослідження.

Ключові слова: виховання дітей раннього віку; освітнє середовище, освітньо-виховний процес у групах раннього віку; особистісний розвиток дитини раннього віку; заклади дошкільної освіти різних типів.

Постановка проблеми в загальному вигляді та їі зв'язок з важливими науковими та практичними завданнями. Один із пріоритетних напрямів реформування вітчизняної освіти забезпечення якісного функціонування системи освіти і виховання дітей раннього та дошкільного віку як самоцінного первинного етапу безперервної освіти.

У законодавчому, нормативно-правовому, програмно-методичному супроводі дошкільної освіти особливо підкреслюється цінність вікового періоду дитини від народження до 3-х років як унікального, найбільш інтенсивного та визначального у становленні і розвитку особистості дитини, ключового у її психофізичному й соціальному розвитку, найбільш сприятливого для соціальних і педагогічних впливів. Періоду, що є сенситивним для становлення і розвитку мовлення, супроводжується інтенсивним розвитком пам’яті, образної уяви і мислення. 
У державних документах наголошується на необхідності удосконалення мережі закладів дошкільної освіти різних форм власності, забезпечення якісних умов для фізичного, психічного, соціального та духовного здоров'я дітей у просторі груп раннього віку, що функціонують у різних типах дошкільних закладів різних форм власності (комунальних, державних, сімейних, приватних, прогулянкових, корпоративних закладів тощо) (Закон, 2001; Концепція, 2021). Це дасть змогу забезпечити рівний доступ для дітей раннього віку до отримання ними якісної освіти і виховання. Утім, у різних типах дошкільних закладів створюються специфічні умови функціонування та виявляються особливості в організації освітньо-виховного процесу в групах раннього віку, що впливає значною мірою на рівень розвиненості і вихованості дітей.

Аналіз останніх досліджень і публікацій з проблеми. Методологічну основу проведеного дослідження становити положення системного, особистісно зорієнтованого, діяльнісного, компетентнісного наукових підходів. В основу обгрунтування сприятливих для розвитку дітей раннього віку умов покладено теоретичні положення концепцій, присвячених вивченню особливостей формування особистості дитини (І. Бех, Ш. Амонашвілі, К. Вентцель, Я. Каменський, Я. Корчак, Й. Песталоцці, Ж. Руссо, В. Сухомлинський та ін.); праць з організації роботи у групах раннього віку сучасних ЗДО (Л. Артемова, О. Богініч, А. Богуш, С. Васильєва, Т. Гурківська, О. Кононко, К. Крутій, С. Кузьменко, Т. Науменко, Т. Поніманська, В. Рагозіна).

Сучасна теорія педагогіки раннього віку грунтується на класичних працях попередніх десятиліть (Н. Аксаріна, П. Бачинський, Т. Бауер, Дж. Брунер, М. Кистяковська, М. Кольцова, М. Красногорський, М. Щелованов та ін.).

Теоретичні засади феномену раннього дитинства закладено у вітчизняних дисертаційних дослідженнях останніх років (I. Гречишкіна (2020), Н. Вахняк (2021), I. Макаренко (2009), В. Паніна (2013), О. Саприкіна (2008), Н. Шкляр (2019), де викладено, у тому числі, й окремі аспекти організації раннього розвитку дітей в умовах різних типів дошкільних закладів.

Науковці наголошують, що характерним для сучасної ситуації в українській системі дошкільної освіти $\epsilon$ не лише кількісне збільшення мережі, а й розширення та урізноманітнення типів закладів, що, на думку С. Васильєвої, зумовлено низкою причин (міграційні процеси, зумовлені соціально-політичними і соціально-педагогічними чинниками, фінансове розшарування сімей, зниження рівня педагогічного просвітництва тощо) (Васильєва, 2017).

У сучасній типології закладів дошкільної освіти, представленій у проєкті Закону про дошкільну освіту (Ст. 13-14), названо дитячий садок, дитячий будинок, будинок дитини, центр розвитку дитини, дитячий садок комбінованого типу, дитячий садок сімейного типу, дитячий садок компенсуючого типу (спеціальних і санаторних) (Закон, 2001).

Вивчення специфіки функціонування груп раннього віку та особливостей організації освітньо-виховного процесу в різних типах ЗДО відбувалося в межах науково-дослідної роботи «Виховання дітей раннього віку в закладах дошкільної освіти різних типів», яка тривала протягом 2019-2021 років на базі дошкільних закладів одинадцяти областей України (Гавриш, 2020). Специфіку функціонування груп раннього віку в різних типах дошкільних закладів (вона виявляється в особливостях організації життєдіяльності в розвивальному середовищі групи, просторі свободи дитини, що зумовлює рівень її особистісної активності та впливає на становлення і розвиток особистісних якостей малюка, його психічні процеси; характері взаємин між педагогами і батьками; позиції вихователів тощо) автори пояснюють наявністю або відсутністю специфічних якостей, які група набуває в результаті її способу зв'язку із зовнішнім світом, її зв'язку з іншими соціальними інституціями (Гавриш, 2020). Специфіка в організації життєдіяльності дітей зумовлюється також обраною моделлю розвивального середовища та освітньо-виховного процесу в групах раннього віку. Так, результати проведеного дослідження (С. Васильєва, Н. Гавриш, В. Рагозіна) переконливо довели вплив зовнішнього середовища на внутрішнє середовища закладу, це позначається на меті, функціях, освітньому середовищі груп раннього віку, що, у свою чергу, впливає на програмно-методичне забезпечення, викликає суттєві зміни у змісті, формах здійснення освітнього процесу, режимі дня та плануванні освітніх завдань (Гавриш, 2020). 
До дослідної роботи було залучено міські та сільські ЗДО комунальної та приватної форм власності; центри розвитку дитини з групами короткого і тривалого перебування. До того ж було проаналізовано особливості організації освітньо-виховної роботи з дітьми раннього віку в дитячому будинку.

Формулювання цілей статті. У цій статті маємо намір подати особливості організації життєдіяльності та освітньо-виховного процесу в групах раннього віку закладів дошкільної освіти різних типів.

Виклад основного матеріалу. Як уже відзначалося, вивчення особливостей організації освітньо-виховного процесу в групах раннього віку відбувалося в межах експериментальнодослідної роботи всеукраїнського рівня з теми «Виховання дітей раннього віку в закладах дошкільної освіти різних типів», що тривала з 2019 по 2021 роки. Експериментальними базами дослідження виступили групи раннього віку закладів дошкільної освіти Донецької, Закарпатської, Запорізької, Житомирської, Київської, Рівненської, Сумської, Черкаської, Чернівецької, Харківської, Хмельницької областей, зокрема: двадцяти комунальних ЗДО, міських і сільських, трьох приватних ЗДО, одного НВК, трьох центрів раннього розвитку, двох дитячих будинків.

Вивчення специфіки функціонування груп раннього віку в закладах дошкільної освіти різних типів дало змогу переконатися, що склад учасників освітньо-виховного процесу (діти раннього віку, вихователі, помічники вихователів, керівник ЗДО, вихователь-методист, педагогічні працівники, медичні працівники, помічники вихователів, батьки або особи, які їх замінюють, та фізичні особи, які надають освітні послуги у сфері дошкільної освіти) може варіюватися залежно від форми власності закладу та інших аспектів його функціювання. Так, малокомплектні сільські дошкільні заклади, приватні центри розвитку дитини не можуть відповідати повній структурі, а саме: обов'язковій наявності методичної, медичної служби, диференціації груп за віком тощо. Отже, структура ЗДО різних типів рухома, динамічна, змінна і не є суттєвою характеристикою для визначення особливостей в організації освітньо-виховного процесу в групах раннього віку.

Науковці, відзначаючи специфіку організації життєдіяльності дітей у групах раннього віку типових і малокомплектних, сільських і міських дошкільних закладів, наголошують на характерних для переважного числа ЗДО спільних ознаках, що виявляються в оформленні та наповненні розвивального середовища груп раннього віку, у підходах до організації освітньо-виховного процесу, що зазвичай ігнорують специфіку розвитку дітей раннього віку; пріоритети в реалізації змісту тощо.

Для унаочнення результатів проведеного порівняльного аналізу зведемо дані в таблицю 1.

Таблиця 1.

\begin{tabular}{|c|c|c|c|c|}
\hline $\begin{array}{c}\text { Параметри } \\
\text { для порівняльного } \\
\text { аналізу ЗДО } \\
\text { різного типу }\end{array}$ & $\begin{array}{c}\text { Комунальні заклади } \\
\text { дошкільної освіти } \\
\text { (сільські, міські) }\end{array}$ & $\begin{array}{l}\text { Приватні } \\
\text { ЗДО }\end{array}$ & $\begin{array}{c}\text { Центри } \\
\text { розвитку дитини }\end{array}$ & $\begin{array}{l}\text { Дитячий } \\
\text { будинок }\end{array}$ \\
\hline $\begin{array}{c}\text { Організація } \\
\text { життєдіяльності } \\
\text { у групах раннього } \\
\text { віку }\end{array}$ & $\begin{array}{c}\text { Жорстка структура; } \\
\text { режим дня; } \\
\text { сітка занять }\end{array}$ & $\begin{array}{c}\text { Гнучка структура; } \\
\text { організація } \\
\text { життєдіяльності } \\
\text { розклад занять }\end{array}$ & $\begin{array}{c}\text { Жорстка } \\
\text { структура; } \\
\text { розклад занять }\end{array}$ & $\begin{array}{c}\text { Жорстка } \\
\text { структура; режим } \\
\text { дня; } \\
\text { сітка занять }\end{array}$ \\
\hline $\begin{array}{c}\text { Модель організації } \\
\text { освітньо-виховного } \\
\text { процесу }\end{array}$ & $\begin{array}{c}\text { занятійна; } \\
\text { інноваційна середо- } \\
\text { вищна (в експери- } \\
\text { мент. закладах) }\end{array}$ & занятійна & занятійна & середовищна \\
\hline $\begin{array}{c}\text { Простір свободи } \\
\text { дитини раннього віку }\end{array}$ & $\begin{array}{c}\text { Регламентований, } \\
\text { відтак обмежений } \\
\text { у переважній } \\
\text { більшості ЗДО }\end{array}$ & $\begin{array}{c}\text { достатній } \\
\text { у більшості } \\
\text { приватних ЗДО }\end{array}$ & $\begin{array}{c}\text { Занадто } \\
\text { регламенто- } \\
\text { ваний }\end{array}$ & $\begin{array}{c}\text { Занадто } \\
\text { регламентований }\end{array}$ \\
\hline
\end{tabular}




\begin{tabular}{|c|c|c|c|c|}
\hline Позиція вихователя & $\begin{array}{c}\text { Організатор; позиція } \\
\text { центрована на } \\
\text { вихователі }\end{array}$ & $\begin{array}{c}\text { Організатор; } \\
\text { позиція } \\
\text { центрована на } \\
\text { вихователі }\end{array}$ & Викладач & Доглядач \\
\hline $\begin{array}{c}\text { Характер взаємин } \\
\text { між педагогами } \\
\text { і батьками вихованців }\end{array}$ & $\begin{array}{c}\text { З більшістю батьків } \\
\text { взаємини напружені }\end{array}$ & $\begin{array}{l}\text { Правила } \\
\text { диктують батьки }\end{array}$ & $\begin{array}{c}\text { Партнерські } \\
\text { стосунки }\end{array}$ & $\begin{array}{c}\text { Відсутність } \\
\text { взаємин }\end{array}$ \\
\hline
\end{tabular}

Для зіставлення було обрано такі параметри: організації життєдіяльності, модель освітньовиховного процесу групи, простір свободи дитини, позиція вихователя, характер взаємин між педагогами і батьками вихованців. Детальніше схарактеризуємо особливості організації освітньовиховного процесу за цими параметрами.

Організація життєдіяльності, освітно-виховного процесу у групах раннього віку в сільських і міських дошкільних закладах комунальної та приватної форм власності істотно відрізняється від такої ж роботи в центрах розвитку дитини (далі - ЦРД). Дослідженням доведено, що на відміну від комунальних дошкільних закладів, переважна більшість (92\%) яких має чітку структуру організації (життя дітей груп раннього і дошкільного віку характеризується суворим режимом дня, який порушувати не можна, освітній процес - сіткою занять, дотримання якого жорстко контролюється); у переважній більшості приватних ЗДО (67\%) - більш гнучка структура організації життєдіяльності: розклад занять, організація життєдіяльності наявні, проте відходження від заявленого дозволяється. ЦРД, що функціонують і на базі ЗДО, але переважно у недержавному секторі, яким опікуються приватні особи чи організації, мають чітку структуру організації життєдіяльності, що зумовлено договірними стосунками з батьками, які сплачують за окреслені послуги. Отже, педагог має послідовно дотримуватися укладеної програми, розкладу занять. Утім має місце гнучкий підхід до складання змісту і спрямування занять у цілому, що зумовлено соціальним замовленням, бажанням батьків максимально розвинути здібності дітей з раннього віку у найкращих умовах для цього, забезпечити всебічний розвиток особистості дитини і розпочати підготовку до навчання у школі якомога раніше (Положення, 2009). Зрозуміло, що порівняно з закладами дошкільної освіти з додатковими послугами, приватні ЦРД мають більш широкий діапазон, який коливається залежно від місця розташування (місто, село), умов, переліку послуг, рівня оснащення та ін. Окремі ЦРД пропонують програму повного дня - із заняттями, харчуванням і денним сном та прогулянками у своєму режимі, що є зручним для батьків, які працюють. Для дітей встановлюють ігрові кімнати з сухими басейнами, гірками, ігровими комплексами, батутами, облаштовують прибудинкову територію та ін.). Але в переважній більшості центрів надання освітніх послуг передбачене короткотривале перебування дітей у форматі різного роду занять, спільної пізнавально-ігрової діяльності тощо. Зауважимо, що поступово зростає число закладів дошкільної освіти, які також починають пропонувати батькам послуги такого типу.

$€$ спільне і відмінне в організації освітньо-виховного процесу в групах раннього віку ЗДО та ЦРД. Спільним $є$ те, що незалежно від форми власності і типу ЗДО чи ЦРД діти набувають освіти відповідно до освітнього стандарту - Базового компонента дошкільної освіти України, який реалізується шляхом дотримання вимог програм дошкільної освіти. Педагоги дошкільних закладів, як і ЦРД можуть обирати будь-яку з чинних програм дошкільної освіти, а також розробляти власну (що має бути затвердженою відповідними органами). Отже, діти раннього віку можуть розвиватися за авторськими програмами; їх різноманіття - це одна з особливостей освітньої роботи і дошкільних закладів і ЦРД. ЦРД та дошкільні заклади сьогодні намагаються більше уваги приділяти роботі з батьками вихованців, надаючи перевагу адресним формам, а не формальними масовим заходам (консультаційна допомога логопеда, психолога, вузьких фахівців та ін., клуб батьків, школа молодих сімей тощо). Успішній реалізації змісту освітньо-виховного процесу в групах раннього віку має сприяти відповідна модель організації освітньо-виховного процесу. Утім, на етапі проведення констатувального дослідження було доведено, що для всіх 
груп раннього віку, що взяли участь в експерименті, характерною була занятійна модель організації освітньо-виховного процесу. Цій моделі притаманне домінування загальногрупового заняття як основної форми освітньої діяльності. Освітня робота індивідуального спрямування в розвивальному середовищі групи не була технологізованою і поширеною. Але така модель суперечить природі дітей раннього віку. Експериментальним ЗДО було запропоновано впровадження середовищної моделі, орієнтованої на пріоритет умов для самовизначення дитиною видів активності в розвивальному середовищі групи раннього віку. Отже, переважна більшість закладів дошкільної освіти залишається в межах традиційного стандартного підходу до реалізації змісту дошкільної освіти.

ЦРД на базі ЗДО переважно працюють з малюками від 2-х років; приватні ЦРД - 3 дітьми від 2-х місяців. У ЦРД дітей об’єднують за віком у малі підгрупи з 5-7 осіб. Як правило батьки $€$ обов'язковими учасниками занять. Тоді як у групах раннього віку дошкільних закладів переважають загальногрупові та підгрупові форми організації дітей, що не передбачають присутності батьків як учасників освітньої діяльності. До того ж для малокомплектних дошкільних закладів характерним є функціонування змішаних груп.

«Сітковий» підхід до планування і проведення занять, що є основною формою роботи з дітьми в ЦРД, також є основним, адже це пов’язано з розподіленням у просторі і часі освітніх послуг, що надає заклад. Сам спектр пропонованих занять $є$ більш сучасним, модерновим і відповідає на виклики батьків (бейбі-йога, фітнес з малюками, бейбі-танці, музика і театр для малюків та ін.). До того ж керівництво переважної більшості ЦРД позиціонують свою освітню діяльність як прихильники однієї з всесвітньо відомих педагогічних систем (М. Монтессорі, Ж. Далькроз, Ф. Фрьобель, Р. Штайнер), щоб зробити ії більш привабливою і затребуваною батьками вихованців. Отже, педагоги ЦРД нерідко виявляють більшу мобільність у реагуванні на запити батьків - створюються нові курси, програми, запроваджують цікаві методики розвитку дітей. Хоча все більше державних закладів також прагне реалізовувати інновації і взаємодіє з науковцями науково-дослідних установ, викладачами вищої школи та ін.

Основною формою організації діяльності дітей у дошкільному закладі й у ЦРД є заняття (як правило - комплексне). Проте якщо у садочку такі заняття проводяться щодня, 1-2 заняття згідно з розкладом, то у ЦРД комплексні заняття проводять з малюками кілька разів на тиждень. Тривалість заняття може коливатися від 12-15 хв. до 50-хвилин (комплексні заняття з батьками у ЦРД). Практика залучення батьків до участі у спільних з дітьми заняттях може бути віднесена до переваг, оскільки це дає змогу малюкам легше адаптуватися до середовища дитячого дошкільного закладу швидше, легше навчитися орієнтуватися у просторі і часі, взаємодіяти у дитячому колективі, спілкуватися.

Знайомство 3 досвідом роботи ЦРД в умовах карантинних обмежень дало змогу зробити висновок про динаміку змін: більшість ЦРД обмежили свою діяльність наживо і, мобільно реагуючи на обставини, переносять ії в онлайн формат: створюють групи батьків, запроваджують навчання через мережу інтернет, проводять різні форми дозвілля тощо. Зауважимо, що і дошкільних закладах ця ситуація була осмислена і опрацьована педагогами і керівництвом дошкільних закладів. Проте значно менше число батьків зголосилися співпрацювати разом із педагогами в онлайн-форматі за об’єктивних і суб'єктивних причин. Тож карантинні обмеження негативно вплинули на забезпечення якості реалізації освітньо-виховних завдань у групах раннього віку дошкільних закладів різних типів.

На відміну від ЗДО і ЦРД освітньо-виховний процес у дитячих будинках відбувається за середовищною моделлю. Але це пов'язано не з прогресивністю поглядів педагогів дитячих будинків, а з тим, що переважна більшість малюків, які виховуються в дитячих будинках, мають особливі освітні потреби і потребують допомоги фахівців. Тож для узгодженості їх дій, що проводяться лише в індивідуальному форматі, зумовлює потребу в середовищній моделі.

Третім типом ЗДО у межах проведеного дослідження було обрано будинок дитини, що визначається як особливий заклад у системі суспільного виховання дітей раннього віку, який має 
замінити сім’ю малятам від 0 до 3 років, оскільки вони залишилися без батьківського піклування, та створити сприятливі умови для забезпечення повноцінного, своєчасного розвитку вихованців, соціально адаптувати їх до подальшого життя у суспільстві, сформувати в майбутньому компетентну, самостійну особистість (Мойсеєнко, 2003; Паніна, 2013; Дубровина, 1990).

Вибір моделі організації освітньо-виховного процесу міцно пов'язаний з двома іншими параметрами - простором свободи і позицією вихователя. Варто пояснити, що у вихованців комунальних ЗДО простір свободи обмежений, оскільки занятійна модель організації освітньовиховного процесу є занадто регламентованою. I такий підхід не може позитивно впливати на активність дітей, виховання їх самостійності та ініціативності. А центрована на собі позиція вихователя, який домінує над дітьми, організує процес пізнання та керує ним, не стимулює, а обмежує процес сприймання й уяви. У більшості приватних дошкільних закладів, які працюють за методиками М. Монтессорі (грунтується на теорії вільного виховання), Вальдорфською методикою, системою Фрьобеля, японськими методиками, простір свободи достатній, тож це сприяє становленню і розвитку таких базових якостей, як активність, самостійність та ініціативність. Можливість для малюків самовизначатися з різними видами активності в розвивальному середовищі групи стимулює розвиток і пізнавальних психічних процесів.

Надмірна регламентація властива і ЦРД, що пов’язано, як ми відзначали, із необхідністю для адміністрації і педагогів відповідати запитам й очікуванням батьків як замовників послуг. Тож діти добре виконують завдання за зразком, за вказівкою педагога, але відчувають труднощі у самовизначенні і самостійній грі.

Недостатнім $є$ простір свободи і дітей-сиріт. У виховній системі дитбудинку майже не передбачено виявлення бажань дитини, надання допомоги в їх реалізації. Традиційно будь-який прояв ініціативності, активності й самостійності з боку дитини жорстко регламентується, контролюється, активність дітей, коли вона проявляється, не знаходить відгуку у дорослих. Свобода вибору, як і можливість самостійного прийняття рішення, практично виключена, що створює дискомфорт й пригнічує енергію вихованця, тобто головний емоційний зв'язок із дорослим реалізується саме через почуття провини. (М. Лісіна, М. Коренєв). У такий спосіб дитина отримує особистісний досвід, з якого виключено ії почуття, переживання. Більш того, вона засвоює правило: стримувати свої почуття вигідно, а виявляти - небезпечно, ось чому внутрішня самотність $\epsilon$ нормою для вихованців дитячих будинків (І. Дубровіна, О. Рузськая).

За даними В. Паніної (2013), присвяченого вихованню дітей третього року життя - вихованців дитячих будинків, багато дітей, які виховуються в будинку дитини, пройшли складні життєві ситуації, відчули на собі свавілля дорослих, сексуальне насильство, алкоголізм, наркоманію, тобто мали достатньо факторів ризику й стресів для порушень психосоціального розвитку. Результатом переживання таких травмуючих ситуацій є втрата у дитини відчуття захищеності і, як наслідок, ускладнення у становленні самосвідомості (переживання власної неповноцінності), порушення соціальної адаптації. За даними наукових досліджень, основними причинами різноманітних відхилень особистісного розвитку дітей, позбавлених батьківського піклування є такі: дефіцит спілкування на рівні дитина-дорослий; специфічність системи спілкування 3 дорослими та однолітками; емоційно-дистанційний стиль взаємодії дитини та дорослого; синдром «великого колективу», що усуває й ускладнює диференційований підхід до дітей; недостатність умов для задоволення особистісних потреб дітей, їхнього саморозвитку і самореалізації (Дубровина, 1990, с. 241).

Порівняння результатів дослідження виховного процесу в дитячому будинку з особливостями виховного процесу в дошкільних закладах, проведеного В. Паніною, дало змогу констатувати, що за своїм психічним розвитком діти, які виховуються без батьківського піклування, відстають від зазначених норм майже у 98\% випадках. Темп розвитку цих дітей повільний. Вихованці в будинку дитини виявляють значно більшу цікавість до дорослого, ніж діти з дошкільного закладу. Вони у будь-який спосіб намагаються заволодіти увагою дорослого: просяться до рук, намагаються щось зробити для дорослого, не хочуть втрачати контакт із ним. I всі ці осо- 
бливості впливають на особливості життєдіяльності дітей, на позицію дорослих, які передусім мають виконувати функцію догляду, а вже потім вихователя і научителя. Це підтверджується і в працях В. Котирло, М. Лісіної, Ю. Разенкової, які стверджують, що діти, які виховуються в закритому закладі, відчувають загострену потребу в увазі та доброзичливому ставленні дорослого (Коренєв, 2003; Пантохина, 1983). За дослідженнями М. Лісіної, у трирічних малюків із будинку дитини помітна пасивність у всіх видах діяльності (особливо у грі), бідне за змістом та лексико-граматичним складом мовлення, слабка увага, відсутність ініціативності, конфлікти у взаємовідносинах з однолітками.

Тому позиція педагога ЗДО і дитячого будинку принципово відрізняється, що випливає з особистісних проявів у дітей.

Поведінку більшості малюків, які виховуються в дошкільному закладі, можна схарактеризувати як емоційну і вільну. Діти зацікавлено дивляться мультфільм, бурхливо та безпосередньо висловлюють свої емоції, охоче вступають у розмову з вихователем.

Маленькі вихованці ж будинку дитини зазвичай поводяться менш активно: рідко посміхаються, рухи маловиразні, оціночні судження відсутні, словник відрізняється бідністю, граматичне оформлення речень із помилками.

Відмінність спостерігається й у вмінні чи невмінні зосереджуватися на завданні, діяльності, якою займається дитина. Так, діти з будинку дитини не могли зосередитися більш, ніж на три хвилини, відволікались на предмети довкілля, намагалися встановити контакт із дорослим, ставили запитання; їхню увагу було розпорошено, вона швидко перемикалася на інший в полі зору предмет. Вихованці дошкільних закладів виявляли більшу зосередженість на предметному змісті спільної діяльності, ініціативу у дії з предметом та бажання діяти, більшість малюків виявляла здатність дитини захоплюватися предметом і діяти з ним. Спільним же для вихованців дитячих будинків і ЗДО виявилося характерна для дітей третього року життя постанова абсурдних і неприйнятних цілей, які неможливо чи небезпечно реалізовувати, відсутність уміння організовувати свої дії, робити їх досяжними (І. Дубровіна, Г. Рузська, Н. Толстих).

До того ж відмінним у позиції педагогів дошкільних закладів, ЦРД та дитячого будинку є їхні ціннісні пріоритети. Так, якщо в ЗДО і ЦРД для вихователів важливо досягти позитивної динаміки у вихованні таких базових якостей, як самостійність, активність, ініціативність, комунікабельність, то для працівників дитячих будинків зазвичай важливішими стають такі якості, як дисциплінованість, підкорення, вміння діяти за вказівками.

Незадоволеність потреби в увазі і теплоті, починаючи з самого раннього дитинства, емоційна бідність й одноманітність контактів, спрямованих в основному на регламентацію поведінки, позбавляють дітей усвідомлення своєї унікальності, необхідності й цінності для інших, суттєво ускладнюють формування повноцінної особистості та власне самостійності. Отже, поведінка вихованців будинку дитини істотно відрізнялась від поведінки дітей-вихованців дошкільного закладу, контакти вихованців будинку дитини виражено слабше, їх можна характеризувати як одноманітні та малоемоційні.

Аналіз організації освітньо-виховного процесу в дитячих будинках та закладах дошкільної освіти дав змогу становити відмінності у підходах дорослих працівників обох типів закладів.

Саме це відрізняє дітей-сиріт від вихованців дошкільних закладів, переважна більшість яких зростають у більш сприятливих психологічних умовах. У всіх вихованців будинків дитини науковці помічають різного типу порушення, характерні для синдрому емоційної деривації; зниження активності й депресивний настрій аж до «депресивного аутизму»: стереотипні рухові акти, які переходять у патологічні дії (смоктання пальців, язика, кусання нігтів, смоктання одягу, підплигування, розкачування тулубом або повороти голови); психоматичні розлади різного ступеня; загальмованість пізнавальних реакцій, псевдо затримки пізнавальних функцій (В. Паніна).

Спостереження за діями, позицією педагогів будинку дитини та ЗДО дали змогу виявити такі наслідки: спільну для різних умов залежність між здатністю малюка діяти самостійно та його умінням співпрацювати з дорослим: чим істотніша і своєчасніша участь дорослого на по- 
чатковому етапі оволодіння дитиною діяльністю, тим більше самостійним вона опиняється в подальшому (Прихожан, 2005, с. 68).

Ще одну відмінність варто відзначити, яка стосується пристосування дітей до нових умов життя як у ЗДО, так і в будинку дитини. Діти, які виховуються у будинках дитини, мають менше можливостей для тренування адаптаційних механізмів і, відповідно, виявляють нижчий рівень соціальної адаптованості. Постійне перебування в стереотипних умовах групи, обмежені контакти із зовнішнім світом призводять до закріплених стереотипів поведінки в статичних умовах. Тому будь-яка зміна умов (переведення до іншої групи, до дитячого будинку, госпіталізація) $\epsilon$ сильним стресовим фактором для вихованців. Особливості пристосування малюка до нових соціальних умов дошкільного закладу, схарактеризовані в дослідженні Н. Шкляр (2019) і підтверджують факт, що, хоч малюки по-різному й проживають процес адаптації, але їх поведінка суттєво відрізняється від поведінки дітей-сиріт (Шкляр, 2019).

Висновки та перспективи подальших досліджень. Отже, висвітлені окремі результати дослідження проблеми організації освітньо-виховного процесу з дітьми раннього віку в закладах дошкільної освіти різних типів, здійсненого на базі лабораторії дошкільної освіти і виховання Інституту проблем виховання НАПН України за участю закладів дошкільної освіти України засвідчили наявність спільних та відмінних ознак в організації життєдіяльності, моделі організації освітньо-виховного процесу в закладах дошкільної освіти, центрах розвитку дитини, будинках дитини; у підходах і позиції педагогів до взаємодії з дітьми як чинника, що впливає на розвитку особистісних якостей малюків; проявах малюків як результат розвитку і виховання в різних соціальних умовах. Один із перспективних напрямів подальшого дослідження проблеми полягає у дослідженні специфіки у взаємодії педагогів з батьками вихованців чи осіб, які їх заміщують в умовах закладів дошкільної освіти різних типів.

\section{Використані джерела}

[1] Васильєва, С.А. (2017). Тенденції розвитку системи дошкільних навчальних закладів різних типів в Україні (друга половина XX - початок XXI століття): автореф. дис. канд. пед. наук. Миколаїв: МНУ імені В.О. Сухомлинського.

[2] Гавриш, Н.В., Рагозіна, В.В., Васильєва, С.А. (2020). Моделювання освітнього процесу в групах раннього віку. Збірник наукових праць Інституту проблем виховання НАПН України «Теоретико-методичні проблеми виховання дітей та учнівської молоді». Bun. 24, 85-105.

[3] Гурковська, Т. (2007). Дитина до трьох: психологічний портрет з рекомендаціями. Дошкільне виховання.12, 11-15.

[4] Дубровина, И.В., Рузская, А.Г. (ред.). (1990). Психическое развитие воспитанников детского дома Москва: Педагогика.

[5] Закон «Про дошкільну освіту». (2001). URL: https://zakon.rada.gov.ua/laws/show/2628-14\#Text

[6] Кольцова, М. (1973). Двигательная активность и развитие функций мозга ребенка. Москва: Педагогика.

[7] Концепція освіти дітей раннього та дошкільного віку: новий погляд. Наукова доповідь на засіданні Президії НАПН України 27 лютого 2020p. (17.01.2021 p.). URL: https://visnyk.naps.gov.ua/index.php/ journal/article/view/43/69

[8] Коренєв, М.М., Лебець, І.С., Моісеєнко, Р.О. (2003). Медико-психологічні та соціальні проблеми та соціальні проблеми дітей-сиріт. Харків-Київ.

[9] Лангмейер, Й., Матейчек, 3. (1984). Психическая депривация в детском возрасте. Прага: Авиценум.

[10] Мойсеєнко, Р.О. (2003). Наукове обгрунтування системи медико-соціальної допомоги дітям-сиротам і дітям, позбавленим батьківського піклування, у державних інтернатних закладах: дис. канд.мед.наук. Харків.

[11] Новоселова, С.Л. (2000). Генетически ранние формы мышления. Москва: МПСИ, Воронеж: МОДЭК.

[12] Паніна, В. (2013). Виховання самостійності у дітей третього року життя в умовах дитячих будинків: дис.канд.пед.наук. Луганськ: ЛНУ.

[13] Пантюхина, Г.В., Печора, К.Л., Фрухт, Э.Л. (1983). Диагностика нервно-психического развития детей первых трёх лет жизни. Москва: Просвещение. 
[14] «Положення про центр розвитку дитини». Постанова Кабінету міністрів України від 05.10.2009 р. № 1124. URL: https://zakon.rada.gov.ua/laws/show/1124-2009-\%D0\%BF\#

[15] Прихожан, А., М. (2005). Психология сиротства. Санкт-Пебергбург: Питер.

[16] Раттер М. (1987) Помощь трудным детям Москва: Прогресс.

[17] Шкарлет, С. (2021). Новий базовий компонент дошкільної освіти забезпечить підвищення ії якості та відповідність міжнародним стандартам (17.01.2021 p.). URL: https://mon.gov.ua/ua/news/novij-bazovijkomponent-doshkilnoyi-osviti-zabezpechit-pidvishennya-yiyi-yakosti-ta-vidpovidnist-mizhnarodnimstandartam-sergij-shkarlet

[18] Шкляр, Н. (2019). Формування позитивного ставлення у дитини четвертого року життя до закладу дошкільної освіти: автореф.дис.канд.пед.наук. Київ: ІПВ НАПН України.

\section{References}

[1] Vasylieva, S.A. (2017). Tendentsii rozvytku systemy doshkilnykh navchalnykh zakladiv riznykh typiv v Ukraini (druha polovyna KhKh - pochatok KhKhI stolittia): avtoref. dys. kand. ped. nauk. Mykolaiv: MNU imeni V.O. Sukhomlynskoho. (in Ukrainain).

[2] Havrysh, N.V., Rahozina, V.V., Vasylieva, S.A. (2020). Modeliuvannia osvitnoho protsesu v hrupakh rannoho viku. Zbirnyk naukovykh prats Instytutu problem vykhovannia NAPN Ukrainy «Teoretyko-metodychni problemy vykhovannia ditei ta uchnivskoi molodi». Vyp. 24, 85-105. (in Ukrainain).

[3] Hurkovska, T. (2007). Dytyna do trokh: psykholohichnyi portret z rekomendatsiiamy. Doshkilne vykhovannia.12, 11-15. (in Ukrainain).

[4] Dubrovina, I.V., Ruzskaya, A.G. (red). (1990). Psihicheskoe razvitie vospitannikov detskogo doma. Moskva: Pedagogika. (in Rusian).

[5] Zakon «Pro doshkilnu osvitu». (2001). URL: https://zakon.rada.gov.ua/laws/show/2628-14\#Text (in Ukrainain).

[6] Koltsova, M. (1973). Dvigatelnaya aktivnost i razvitie funktsiy mozga rebenka. Moskva: Pedagogika. (in Rusian).

[7] Kontseptsiia osvity ditei rannoho ta doshkilnoho viku: novyi pohliad. Naukova dopovid na zasidanni Prezydii NAPN Ukrainy 27 liutoho 2020r. (17.01.2021 r.). URL: https://visnyk.naps.gov.ua/index.php/journal/article/ view/43/69 (in Ukrainain).

[8] Koreniev, M.M., Lebets, I.S., Moiseienko, R.O. (2003). Medyko-psykholohichni ta sotsialni problemy ta sotsialni problemy ditei-syrit. Kharkiv-Kyiv. (in Ukrainain).

[9] Langmeyer, Y., Mateychek, Z. (1984). Psihicheskaya deprivatsiya v detskom vozraste. Praga: Avitsenum. (in Rusian).

[10] Moiseienko, R.O. (2003). Naukove obgruntuvannia systemy medyko-sotsialnoi dopomohy ditiam-syrotam i ditiam, pozbavlenym batkivskoho pikluvannia, u derzhavnykh internatnykh zakladakh: dys. kand.med.nauk. Kharkiv. (in Ukrainain).

[11] Novoselova, S.L. (2000). Geneticheski rannie formyi myishleniya. Moskva: MPSI, Voronej: MODEK. (in Rusian).

[12] Panina, V. (2013). Vykhovannia samostiinosti u ditei tretoho roku zhyttia v umovakh dytiachykh budynkiv: dys.kand.ped.nauk. Luhansk: LNU. (in Ukrainain).

[13] Pantyuhina, G.V., Pechora, K.L., Fruht, E.L. (1983). Diagnostika nervno-psihicheskogo razvitiya detey pervyih trëh let jizni. Moskva: Prosveschenie. (in Rusian).

[14] «Polozhennia pro tsentr rozvytku dytyny». Postanova Kabinetu ministriv Ukrainy vid 05.10.2009 r. № 1124. URL: https://zakon.rada.gov.ua/laws/show/1124-2009-\%D0\%BF\# (in Ukrainain).

[15] Prihojan, A., M. (2005). Psihologiya sirotstva. Sankt-Pebergburg: Piter. (in Rusian).

[16] Ratter M. (1987) Pomosch trudnyim detyam Moskva: Progress. (in Rusian).

[17] Shkarlet, S. (2021). Novyi bazovyi komponent doshkilnoi osvity zabezpechyt pidvyshchennia yii yakosti ta vidpovidnist mizhnarodnym standartam (17.01.2021 r.). URL: https://mon.gov.ua/ua/news/novij-bazovijkomponent-doshkilnoyi-osviti-zabezpechit-pidvishennya-yiyi-yakosti-ta-vidpovidnist-mizhnarodnimstandartam-sergij-shkarlet (in Ukrainain).

[18] Shkliar, N. (2019). Formuvannia pozytyvnoho stavlennia u dytyny chetvertoho roku zhyttia do zakladu doshkilnoi osvity: avtoref.dys.kand.ped.nauk. Kyiv: IPV NAPN Ukrainy. (in Ukrainain). 
Nataliia Havrysh, Chief Researcher of the Laboratory of Preschool Education and Upbringing of the Institute of Educational Problems of the National Academy of Educational Sciences of Ukraine, Doctor of Pedagogical Sciences, Professor; Kyiv, Ukraine.

\section{FEATURES OF THE ORGANIZATION OF THE EDUCATIONAL PROCESS IN EARLY AGE GROUPS OF PRESCHOOL EDUCATION INSTITUTIONS OF DIFFERENT TYPES.}

The article presents the features of the organization of the life and educational process in the early age groups of preschool education institutions (PEI) of different types.

The study of the specifics of the functioning of early age groups and features of the organization of the educational process in different types of PEI took place within the research work "Education of young children in preschool education institutions of different types", which lasted during 2019-2021 on the basis of preschool education institutions in eleven regions of Ukraine.

In the process of research work, urban and rural PEI of communal and private forms of ownership were involved; child development centers (CDC) with groups of short and long stay. In addition, the peculiarities of the organization of educational work with young children in the orphanage were analyzed.

The following parameters were chosen to compare the features of the organization of the educational process in preschool education institutions of different types: organization of life; model of the educational process of the group; the space of the child's freedom; the position of the educator; the nature of the relationship between teachers and parents of children.

It is proved that the organization of the life and educational process in early age groups in rural and urban preschool education institutions of communal and private forms of ownership differs significantly from the same work in child development centers.

All groups of early age participated in the experiment are characterized by a busy model of the organization of the educational process. This model is described by the dominance of group activity as the main form of educational activity.

Teachers of child development centers often show greater mobility in responding to parental requests - new courses, programs are created, interesting methods of children's development are introduced. Although more and more public institutions also seek to implement innovations and interact with scientists from research institutions, high school teachers, and others.

In contrast to PEI and CDC, the educational process in orphanages takes place in an environmental model. But this is not due to the progressive views of orphanage educators, but rather to the fact that the vast majority of children raised in orphanages have special educational needs and require professional help.

Keywords: upbringing of young children; educational environment, educational process in early age groups; personal development of a young child; preschool education institutions of different types. 